Journal of Social Sciences (COES\&RJ-JSS)

ISSN (E): 2305-9249 ISSN (P): 2305-9494

Publisher: Centre of Excellence for Scientific \& Research Journalism, COES\&RJ LLC Online Publication Date: $1^{\text {st }}$ July 2016

Online Issue: Volume 5, Number 3, July 2016

http://centreofexcellence.net/J/JSS/JSS\%20Mainpage.htm

\title{
Designing scientific learning models application in low-grade of primary schools based on the 2013 curriculum in East Java, Indonesia
}

\author{
HM. Zainuddin \\ Lecturer of KSDP UniversitasNegeri Malang, East Java, Indonesia \\ E-mail: hm_zainuddin@yahoo.com
}

\begin{abstract}
:
The Implementation of 2013 curriculum is associated with The Decree of State Human Resource Empowerment Ministry No. 16 RB. Positive strategic steps need to be done to prepare students and teachers to implement 2013 curriculum in terms of designing scientific learning models based on PP 103 in 2014. This research was aimed at describing the scientific learning models applicative design to implement the 2013 curriculum for low-grade primary school students. This research was done in two stages, which are, designing scientific learning models of elementary school based on curriculum 2013 and implementing scientific learning models to students of grade 1,2,3 of Ma'arif Islamic International primary School in Blitar using a model teacher trained by the Primary School Teacher Undergraduate Program of State University of Malang. This research turned out to show that the practical activities and comprehensive training on designing the wake scientific approach teaching model to implement the 2013 primary school curriculum are able to improve the teachers' competence as well as teacher trainees' competence.
\end{abstract}

Keywords:

2013 curriculum, competence, scientific models

\section{Citation:}

Zainuddin, HM (2016); Designing scientific learning models application in low-grade of primary schools based on the 2013 curriculum in East Java, Indonesia; Journal of Social Sciences (COES\&RJ-JSS), Vol.5, No.3, pp: 229-237. 
National Education serves to develop and form the character and civilization of the nation's dignity in the context of educating the nation (UURI nomor20tahun2003 tentangSistemPendidikanNasional). This serves to develop the entire potential of learners to "become a man of faith and devoted to God Almighty, noble, healthy, knowledgeable, skilled, creative, independent, and become citizens of a democratic and responsible (UURI nomor20tahun2003 tentangSistemPendidikanNasional).

Education should provide a basis for the sustainability of the nation's life in all aspects of national life that reflects the character of the nation today. Educational content should not concern with those related to the great achievement of the nation's past, but also those need to be succeeded at present as well as to be sustained for the future. New developments in science, technology, culture, economy, social matters, politics, nation and mankind are packaged as educational content. Careful observation shows that it has not been in line with the role of studentsand teachers who are supposed to be the motors of curriculum development. Based on the survey results and interviews with students conducted in the first semester of 2015 by the Primary School Teachers Program of the State University of Malang team, there have been found out that the teachers' understanding of the 2013 curriculum, public test, and the principles of its development has not been adequate. It is highly necessary to work for the positive measures in the form of scientific orientation activities related to the curriculum in 2013 against the Primary School Teacher Program students. Students must understand the scientific study model as stated in the Government decree no 103, 2014. The scientific approach or process-based approach to science refers to paragraph (7) of the decree asorganizing a learning experience with a logical sequence that includes the learning process covering the process of observing, questioning, collect information / try (data collecting), reasoning / processing information (associating), communicating. Scientific approach relates to learning approach in such a way that these enable students to learn by giving direct experience through the scientific stages, not those such as feeling, inclination, intuition, or guessing. These develop and employ learning model or method called Discovery Learning, Problem Based Learning,and Project Based Learning. Implemented in the 2013 cuurriculum, these need positive measures in the form of student preparation strategies in order to wake scientific learning model design based on the Government decree No 103, 2014.

The fact above was still associated with the decision of the decree of the Indonesia Republic State Minister of Administrative Reform No. 16/2009 on Functional Master and credit figures seen as an important moment trip of teaching profession in Indonesia. This affirmed that the teacher as a functional position, in which the process of promotion and professorship originally done automatically and periodically changed based on the number of credits, thus allowing the teacher to be able to apply for a promotion and groups of less than 4 years. Although in certain cases, particularly for the promotion of groups IVa to $\mathrm{IVb}$ and beyond, this rule seems to be counter-productive, because many teachers are hampered by regulations requiring teachers to make Essay. Along with the passage of time and the development of the profession and of teacher demands today, the minister's decision apparently needs necessary adjustments. Therefore, the government through the Minister of State for Administrative Reform and Bureaucratic Reform issued new regulations as the decree of the Minister of State for Administrative Reform and Bureaucratic Reform No. 16 of 2009 on Functional Teacher and credit figures. 
Based on the description above, it can be said that Primary School Teachers students embodied the meaning and spirit on educational reform so they need to be given an understanding of the principal key in teaching and learning process (Curriculum 2013) as a tool and new regulations relating to the existence and the urgent development of a new curriculum. To achieve the result of 2013 curriculum, it would require a dynamic change in education through research and development then it will be disseminated to stakeholders of education and students throughout Indonesia. Many things must be considered in the development and the implementation of 2013 curriculum at the elementary school including learning model chosen, the quality of teachers, as well as facilities and learning resources support teaching and learning activities. We need to evaluate and amend these elements for the sake of improving the quality of education. Considering these argumentation, this research was conducted as "Designing Scientific Learning Models Application In Low-Grade Of Primary School Based On 2013 Curriculum"

\section{Research methods}

The research was conducted at the State University of Malang campus PP3 with the cooperation of the International SDI Ma'Arif of Blitar. The subject of the research consists of 90 students. This was a big subject to research, then the implementation of the research was carried out in two stages, beginning with the administration of a questionnaire to collect the data of readiness to face students in low-grade 2013 curriculum and have three students as a model teacher.

The research was done in elementary school in Blitar, namely SDI International Ma'Arif with three levels of classes namely class 1,2 , and 3 . The number of students in grade 1 is 23 (twenty three) students, grade 2 is 19 (nineteen) students, and grade 3 is 18 (eighteen) students.

This research was a development research. The focus of this research was thatto develop or to produce a product in the form of a model in order to improve the quality of learning. This is in line with the opinion of Ibnu (2013: 3) that Research development is not to test the theory, but to develop and test the effectiveness of the model. Further research and development is to produce the products as a function of creation to improve the quality of learning.

The objective of this development research was to produce the product as a function of development to tackle problems in the learning. Therefore, in development research have the specific characteristics and contextual, problem solving, collaborative, and produce products.

In this research, the data was collected in terms of process data and results data. The process data collection comprises: (1) questionnaire readiness of students in curriculum implementation 2013, (2) interviews on the readiness of the students in the curriculum implementation 2013 in the lower classes, the results data include: (1) Product model that in the CD right for class materials Low in SD, which featured student public university in PP3 Malang State University of Malang.

The data collection instruments used in this research consisted of a questionnaire, interview, and documentation. In this study, there were two types of data were analyzed, namely data and process the data results. 


\section{Research result \\ Designing Scientific Learning Model}

The scientific learning model design, according to Ibnu (2014) consists of the planning, exploration, early product development, and validation stage. In the planning stage, educators reviewing the curriculum syllabus 2013, and then make the appropriate syllabus or lesson plan under Regulation 103 of 2014, setting up a book teachers and students according to the syllabus, preparing LKPD (Activity Sheet Students), set up in accordance sub theme media, and designing and making judgments attitudes, knowledge, and skills. The exploration stage activities are to acquire new experiences of the new situation. In exploration activities, teachers engage learners in searching and collecting information, using the media to enrich the experience of managing information, facilitate learners to interact so that learners actively, encouraging learners to observe a variety of symptoms, catch the signs that distinguish the symptoms on other events, observe objects in the field and laboratory.

Learners' activities concern gathering information by reading, informal discussion, or trial, and collect and process data. While the activities of the teacher was using a variety of approaches and media, facilitating the interaction between all learners, students with teachers, and learners with learning resources, and actively engage learners. In the early stages of product development, the products developed are appropriate syllabus and lesson plan under Regulation 103 of 2014, teachers book and students suitable syllabus, LKPD (sheet activities of learners), the media according subthemes, assessment rubrics attitudes, knowledge, and skills, scientific models of learning form of CDs, and the article was in national journals. The validation phase, validation was done by experts in the field, in accordance with the development of the instrument. Revised models and devices based on the results of the validation study, this revision is based on product testing by the outside community to improve product quality.

\section{Model Discovery Learning in Grade 1 SDI Maarif Kota Blitar}

Discovery Model of Learning is one of the pilot model used in 2013 curriculum, applied in Grade 1 SDI Ma' Arif Blitar Student model teacher. Students' aspect developed was the attitude of spiritual, social attitudes, knowledge, and skills. This model was designed to lesson plans using a systematic and complete syntax and equipped with a scientific approach. When the teacher opened with greetings learning, students responded with enthusiastic greetings and pray together.

Students then sang the song Good Morning with the teachers with spirit, the students listened well of information materials and the expected goals and do not forget the teacher provides questions stimulation to students in accordance with the material as it ever see the sun and when the students see it. Students read a short description text with pictures on students' books. The teacher asked students to answer with right hand raised in advance and provide answers varied about what is observed in the image. Even students whowere usually shy in the classroom were very enthusiastic to answer because early learning has built his spirit through song. Then, the teachers did not forget remind students to always gave thanks to the creation of Almighty God.

Students were directed to make educated guesses about the causes of the events of the morning through debriefing. No one answered the mornings because of the sun, the moon around the earth, no sun was round and large, the teacher gave praise to those who dare to 
reveal the answer. Students saved allegations and then made the observation of the image so that students can observe and find the differences in each event. After observing, teachers do question and answer to strengthen the notion of students.

The next activity was the students to experiment using a globe and a flashlight with teacher demonstrates first, curiosity of students showed up and tried to find an assortment of countries. Students flashlight toward the globe, the teacher gave the concept that part of the earth facing the light appears bright, which meant the earth experienced the morning and afternoon, while the earth turned dark and the light would be visible means an event night. Then students did exercise on students' worksheet, student discipline to work on the problems. Then the final stage was the model of Discovery Learning is finding the proof in the real environment or the surrounding environment. Students were asked to observe what was seen. Students answer was no sun, clouds, sky, birds fly, and trees. The teacher asked whether the objects seen clearly, the students said yes clearly visible. Upon entry into the classroom, students and teachers make inferences and recall what they learned today. Students express the impression of learning through drawing expressions. Learning activities ended with the provision of home assignments to observe the events of the evening and continued with the closing greeting. Documentation in the form of instructional videos with Project Based Learning models can be seen in www.sdima'arifkotablitar.sch.id

\section{Problem Based Learning Model in grade 2 SDI Maarif Kota Blitar}

Problem Based Learning is a learning model that is designed to the students get the knowledge that makes students proficient in solving problems, and has its own model of learning and have the skills to participate in the team.

On learning about the theme of learning to live harmoniously three familiar symbols in the national precepts of Pancasila, the students rotated Pancasila eagle song and sang it together. When the song playback Garuda Pancasila learners could see the display of images related to Pancasila whether it's an assortment of one's profession, symbols precepts of Pancasila and Garuda (Eagle) emblem. After they screwed the song, a teacher asked what was seen by learners, Various answers mentioned by learners, in this case the teacher continues to explore the thoughts of the students and gave students the opportunity to remember the images that have students view and give the questions to lead to the third principle of the unity of Indonesia reflection of living in harmony.

At the core activities the students observed a banyan tree symbol third principle. The scientific attitude of students began to emerge as to ask the teacher why the banyan tree leaves are lush and green and has a strong stem. More critical learners have asked why the symbol of the banyan tree to represent the unity of Indonesia. The question of the teacher did not immediately answer, but returns the questions that students asked for the students' own responsibility from the experience of playing the game.

In this game the students are invited to make a big circle, turning and singing, at the end of the singing teacher gave instructions to pair eg four, all learners to quickly find each partner so that the even numbered four pairs or eight people on the condition that all should be able to tread paper that had been prepared. From this game message learners could answer what the sense of unity, understanding what living in harmony symbolized the third principle banyan tree. Once students understand the basic concepts followed by working groups of four people to solve a problem that is expected to have many of the 
group's work solutions. The jointly discussed and each member of the group were given the opportunity to speak his mind.

The results of student learning using Problem Based Learning models showed significant progress. It could be seen from the control concept well constructed material. Learners began to show his skills to observe, ask, gather information, to associate and communicate to the problems that have implications for the study of students which were $75 \%$ above the value of students already in standard criteria minimum.

The way students express an interest in learning about the impression of Problem Based Learning model of the attitude of students who enthusiastically participated in the learning as well as the number of points that students can collect in accordance with instrument ratings. Video documentation of the learning model Problem Based Learning can be seen in www.sdima'arifkotablitar.sch.id

Model Project Based Learning in class 3 SDI Ma'Arif of Blitar.

In learning to use the curriculum 2013, with a model of Project Based Learning (PPA) which was done in class 3B SDI Ma'Arif Blitar took place with a conducive and pleasant. Student activity that emerged in this research is the question and answer, discussion, group work. At the beginning of activities was beginning with the greeting, prayer, and attendance. Then, it was continued by students' apperceptions with the students about endangered animals and plants that have been learned in the previous lesson. Apperception was aimed to explore the knowledge of students and prepare students to start the next lesson. In the next activity, the teacher informed the students about the material and learning goals today.

Core activities, carried out by learning to use the model Project Based Learning (PPA), the first stage was the determination of fundamental questions. In this first stage, the activity appeared to question the form of frequently asked questions and watched through the view instructional video related to learning material of animals and plants in Indonesia. Furthermore, students discussed the answers to questions with his friends. The second stage, is designing the project planning. At this stage, the student activity that arises was to collect and process information in discussions and work in groups to work on a project, which was making a poster. The third stage, was drawing up a schedule. At this stage, student activity that appears was the management of time working on projects and discussion among members of the group in scheduling activities and preparing their work on the assignment alternative, if the processing time exceeds the scheduled timetable. The fourth stages, was to monitor learners and the progress of the project. In this phase, teachers guide students in making posters and drive around to check the students' work and helpedstudents who were still experiencing difficulties, so that students could improve poster that was being made. The fifth stage, was to test the results. In this stage, student activity that was communicating through presentations of group work in making the poster, another group of students to provide input in the form of frequently asked questions, criticisms, and suggestions posters presented results. The sixth stages, was the evaluation of the experience. At this stage, student activity concludes the study was a result of creativity in making posters about endangered animals and plants that could be used as a poster-making students experience in creativity during the learning process. 
Then at the end of the learning activity, students conclude learning activities for one day, reflection, and follow-up of learning process. Afterwards, closed activity was a prayer and a greeting.

Scientific attitude of students who appeared was conscientious, meticulous, curiosity on the activity observed instructional video and observed instances of posters. In addition, the emerging active attitude was to the students to ask in determining the fundamental question. At the time of the discussions emerged discipline, responsibility, and creative in doing posters of animals and plants. Students learn to cultivate an attitude of care for endangered animals and plants to maintain and preserve it through the creation of the poster. In the event the project results presentation (poster) appears attitude of courage and responsibility to communicate the results of the project (poster) who has worked with the group of students.

Learning outcomes of students with learning model Project Based Learning (PPA), an excellent and easily followed by almost all students follow the learning process by actively and attentively. The result of research after study was nearly $95 \%$ of students scoring above on standard criteria minimum. Other side, they need guidance in order to adjust the focus to learning. From this learning, students become active and interested in learning fun

Impression on the students' learning model was pleasant and enthusiastic students to participate in learning. How students convey his impression was to deliver moments of reflection, and was seen in almost entirely enthusiastic students who were active in participating in learning activities. Conducive learning took place, as well as the students waited for the next exciting learning. Students conveyed the impression by asking the teacher, the teacher would teach them when to come back and ask what tasks would be done the next person. Another thing also seen on the end of learning, students were reluctant to go out of his seat and still wanted to learn more, but when the learning had been finished for today. Documentation in the form of instructional videos with Project Based Learning models could be seen in www.sdima'arifkotablitar.sch.id

\section{Discussion}

This learning process was intended to serve and facilitate the students to be able to learn as optimally as possible, to its potential in an atmosphere that was conducive physically, mentally and emotionally. The application of scientific learning model was in SDI Ma'Arif Blitar overall raised scientific attitude in students. In these activities, student activity points that could be indicated was the sense of intellectual curiosity (Intellectual curiosity), cognitive abilities and skills in reading, writing, and arithmetic at a lower grade students. The educator was the final semester students of the Primary School Teachers Education Program. The development and design of scientific models based the 2013 curriculum has been showing good results. The lesson plans, instruments, teaching materials and media weremade in accordance with the material. The use of model of learning in core activities was in accordance with the syntax of the chosen learning model. In terms of activity, the students showed an attitude of scientific, the results of student learning shows the attitude of spiritual and social good, the test scores of the so-called LKPD showed students understand the material given, the skills to observe or draw in class 1 are contextual based on observation through a model of Discovery Learning, independence and cooperation is also seen in learning. In grade 2, the instruction was done through models of problem based learning, student activities predominantly on the activity of reasoning and analyzing events around 
The learning models were made by the students of the Primary School Teacher Education Program of the State University of Malang completed with the device of developing scientific models of learning. The result of this learning activity was documented through instructional video full of apperception, core activities, and cover (evaluation and reflection, prayer). Of course, it included media which were appropriate for learning materials at that time.

Learning videos completed with instrument development application of the 2013 curriculum was a product that deserved to be developed and disseminated to the public sphere of education for student learning outcomes. This academically showed good results. The attitude of spiritual and social appeared to be a very good habit. The skill tryal to create a simple product was also shown from the student activity. Fundamentally, all good scientific models could be implemented in both high grade and low grade. These only required understanding and competence of teachers or teacher's trainee to design the instruction as much as possible in accordance with the 2013 curriculum materials.

\section{Conclusions and recommendations}

This research was a development that aimed at producing or developing a product in the form of a model in order to improve the quality of learning. Research development was not to test the theory, but to develop and test the effectiveness of the model and produce as a function of creation to improve the quality of learning and to tackle problems in the learning.

Based on the preceding discussion, conclusions on the development of research were described in the following points: (1) From the process of questionnaires and interviews the research subject, gained 3 college students to design and implement a model of scientific learning in lower grade $(1,2,3)$ SDI Ma 'wise Blitar, (2) the Scientific Learning Model used was a model of Discovery Learning in grade 1, the model of Problem Based Learning in class 2, and the model of Project Based Learning in class 3 SDI Ma'Arif of Blitar.(3) Student teacher model of designing learning activities 1x35 minutes using scientific models with complete learning instrument then implement the SDI students Ma'Arif Kota Blitar, (4) Learning outcomes using scientific models (Discovery Learning, Problem Based Learning, Project Based Learning ) in low grade SDI Ma'Arif Blitar indicates that the model was able to bring the scientific attitude on students, high curiosity, and spiritual attitudes of students in activities to pray or observe activities could bring a sense of gratitude towards God's power.

The output of this research, analysis, evaluation, and reflection on the overall findings can be references to take into account that the characteristics and advantages of the scientific learning model comprises the number of principles relating to the effectiveness of the model in the context of applicable programmed as a recommendation of this development research. Especially to the Ministry of National Education and the staffs, in order to assist in disseminating the product of research and development as one of programmatic efforts in order to improve and increase the quality of basic education through the use of these research products that have been tested empirically-education. Socialization can be done through in-house training programs and seminars, as well as the use of groups of teachers (KKG), which have been formed in each district, so that the products of this research can be assessed and disseminated in a more effective and widespread. For the student teachers, 
the product can be disseminated through seminars and lectures as a student learning materials in implementing the 2013 curriculum later.

Thus, the concerns and difficulties of teachers and student teachers in developing and applying models of scientific research at the primary school level can be reduced and have alternatives and solutions in terms of activities and programmatic focus on researchers and support of the Ministry of National Education.

\section{References}

Dewan Riset Nasional Kemenristek(2010)AgendaRiset Nasional2010-2014.

DirektoratJenderalPendidikanTinggiKemendikbudRI (2010) RencanaStrategis DirektoratJenderalPendidikan Tinggi 2010-2014.

DirektoratPenelitiandanPengabdianKepadaMasyarakatDirektoratJenderal Pendidikan Tinggi KemendikbudRI.(2012)PedomanPenelitianEdisiVIII

KementerianPendidikanNasional (2010)RencanaStrategisKementerian Pendidikan Nasional 2010-2014

Kurukulum 2013 DirektoratPendidikanDasardanmenengah, 2014

LembagaIlmuPengetahuanIndonesia (2012) PanduanPenyusunanProposal KegiatanPenerapandanPemanfaatanIlmuPengetahuandanTeknologi di Daerah (IPTEKDA) LIPIXVITahun 2013.

Ibnu,Suhadi(2013) PenelitianPengembangan. Malang: UM Press

Tinggi KemendikbudRI (2011) PedomanPengabdianKepadaMasyarakat. 